\title{
Revival of the Evenki Language: Traditional and Modern Formats
}

\author{
Natalia N. Seredkina* \\ and Yelizaveta S. Strucheva \\ Siberian Federal University \\ 79 Svobodny, Krasnoyarsk, 660041, Russia
}

Received 06.03.2018, received in revised form 30.03.2018, accepted 03.04.2018

The process of linguistic assimilation, which began as far as in the 1990s, had a strong influence on the decreasing number of the Evenks who speak their native language. At the present stage of language development, the issue of its revival is especially topical and timely. In this article, the authors consider the strategies for revitalizing the Evenki language, connected, on the one hand, with the ongoing traditional practices of preserving the language, and, on the other hand, with the emergence of new modern forms that allow the Evenki language and culture to be used more and to reach a larger audience. Priority directions for the revival of the Evenki language are presented in the article. They include the sustentation of policy aimed at preserving and developing the traditional way of life of the Evenks; language immersion programs; supporting the practice of creating literature in the Evenki language; attraction of a larger audience to the Evenki language through modern Internet technologies.

Keywords: Evenki language, revival, Evenks, Evenki literature, Internet.

The reported study was funded by JSC «Vostsibneftegaz» according to the research project: «Revival of the Evenk's Language».

DOI: 10.17516/1997-1370-0254.

Research area: culturology.

\section{Introduction}

Since the second half of the $20^{\text {th }}$ century, the role of the native language has been decreasing for the Evenks. According to the 2010 census, against an increase in the total population of the Evenks in Russia to 37,843 people, the number of the Evenki language speakers dropped to $12.7 \%$, whereas in $198945.1 \%$ of respondents claimed to be fluent in the Evenki language with a total number of the Evenks in Russia of 29,957. The language situation of the indigenous and smallnumbered peoples of Siberia in the context of global transformations has become the study object of many scientists in recent decades. Researchers have been making expeditions to places where the Kets, Selkups, Chulyms, Evenks, Yakuts and other ethnocultural groups live compactly. The purpose of the research is to analyze the modern influence of ethnic processes on traditional national culture (Amosov et al.,

(C) Siberian Federal University. All rights reserved

* Corresponding author E-mail address: NevolkoN@yandex.ru 
2012; Sitnikova, 2015; Bukova, 2016; Kirko et al., 2017). Extensive material on the dynamics of the native language functioning among the Evenks in the Evenki Autonomous Okrug can be found in the studies of V.P. Krivonogova and E.S. Ermilova (Krivonogov, Ermilova, 2017). This complex ethnographic study was conducted in two stages with 10 years between (in 1997 and 2017). According to the results of a mass poll among the Evenks, scientists cite statistical data indicating a decrease in the Evenki language functioning among representatives of this ethnocultural group. The Evenki language is much inferior to the Russian, which was declared by the majority of respondents as their prevalent spoken language (in 2017 the number of those who stated the Evenki language as their main spoken fell to $0.4 \%$, whereas in 1997 the share of such respondents was $4.3 \%$ ). Only the older generation speak the Evenki language well. In contrast, the number of those who can write and read in Russian is growing. In addition, there is a tendency of fall in the number of schoolchildren who study their mother tongue in general education institutions. Obviously, there is the age dependence in this process. Thus, the majority of respondents studied the Evenki language until $9^{\text {th }}$ grade $(53.3 \%)$, but in the upper grades this percentage decreased to $8.2 \%$. Having grown and being aware of the fact that another language has priority, and more necessary knowledge is gained only through another language the Evenki teenagers decide to choose Russian as the language of communication.

So, the analysis of the contemporary language situation among the Evenks makes it possible to determine the stages of the Evenki language usage. These stages are distinguished according to the development of minority languages model, proposed by the Russian linguist V.M. Alpatov. To date, the Evenki language functions, firstly, as a daily language. Such languages are limited functionally to family, school education (no higher than primary school), fiction. The carriers of such languages, as a rule, are bilingual, which we can observe among representatives of the Evenki ethno-cultural group. The role of such languages might be compared with the role of dialects. School education in such languages acts as an intermediary stage with the following transition to education in the state language later (Alpatov, 2013). Along with this, the Evenki language is at the penultimate stage before the complete language extinction. This stage was called the "language ghetto" in linguistics, as at this stage the language is still remembered and sometimes spoken by individual representatives of the ethnos, but the possibilities for its wide functioning are limited. Consequently the Evenki language "lives" among the Evenks, but it is the language of the older generation rather than the youth who should determine the future for the language. The language is limited functionally only to being studied at pre-school and school institutions for the most part. This situation is not related to the loss of language as such. It is customary to associate this phenomenon with the assimilation of native speakers (Alpatov, 2013). For the Evenki language, as for many other languages of the Siberian ethnic groups, this coming through all these stages is quite characteristic. This is the way from monolinguality as the knowledge of the ethnic language to bilingualism and again to monolingualism, when the spoken ethnic language becomes unfamiliar. In the case of the Evenki language situation, once unfamiliar language is Russian. Based on the observed situation of the decrease in the number of the Evenks who speak their native language and the powerful influence of assimilation processes, largely connected to the greater penetration of the Russian language into all areas of the indigenous communication in the $1990 \mathrm{~s}$, the issue of the language revival is becoming topical and timely 
today. In this article, the authors regard strategies for the Evenki language revival, coupled, on the one hand, with the maintenance of traditional practices of its development, on the other hand, with the emergence of new modern forms for the language actualization.

\section{Literature review}

The problem of the loss of national languages became most evident back in the 1990s, during the period of the Russian language in-coming in the minority language territories (Alpatov, 2013). This situation reflects only a part of those transformations that representatives of the indigenous and small-numbered peoples have been experiencing. K.A. Degtiarenko, V.I. Kirko, M.A. Kolesnik, N.P. Koptseva, N.M. Libakova, K.V. Reznikova, etc. devoted their research to analysis of the contemporary ethnic and cultural situation of the northern peoples. Along with doing extensive cultural and anthropological research, scientists focus on the problem of revitalizing languages that are on the verge of withering and even extinction. The Evenki language is not an exception. Modern researchers believe that in order to preserve the Evenki language, it is necessary, at least, to continue the work started by G.M. Vasilevich, Russian linguist, ethnographer, fine connoisseur of the Evenki language, aimed at describing grammar, vocabulary and phonetics of the language (Andreeva, 2015). This kind of conservation will enable systematization of knowledge and may become a basis for the language revitalization programs. T.E. Andreeva notes that, in connection with the processes characterized by the indigenous peoples forgetting their native language and a decrease in the number of speakers, scientists need to conduct an urgent study of the linguistic heritage of these ethnic groups. According to some researchers (Atknine, 1997; Turaev, 2006), the traditional language is preserved in those settlements where traditional forms of work are relevant, since the language culture of the Evenks is based on them. Therefore, the revival of the Evenki language is considered possible provided that traditional activities such as reindeer herding, fishing and nomadic life are kept. In this connection it is worth mentioning the described by N.A. Mamontova (Mamontova, 2013) project of a nomadic kindergarten. "Nomadic kindergarten" is a project that raises interest not only in the native language, but also in the traditional nomadic way of life with its main attributes in the form of deer herding and chum building. Along with this, the author points out the low effectiveness of this type of mastering the native language, since such behaviour results not in the revival of cultural traditions, but only in the folklorization of the ethnic group. In addition to the nomadic kindergartens, nomadic schools and summer recreational ethnocultural children's camps have been organized at different times in Evenkia. O. Felde specifies that the main purpose and distinguishing feature of such projects is the communication of participants, which occurs in the native language (Felde, 2011).

Free communication in the traditional language among the younger generation is one of the main tasks of the Evenki language revival. K. Struchkov (Struchkov, 2005, 2011), like a number of other scientists, considers daily usage of the language as an obligatory condition for its successful revitalization. Therefore, it is important to address the problem of the language revival not only by reforms and innovations in the educational sphere. V.A. Turaev argues (Turoaev, 2006) that the traditional practice of studying the Evenki language in schools is outdated. Excessive emphasis on grammar without attention to the spoken vocabulary of the language does not give students the necessary knowledge to speak the language fluently. The lack of books and mass media in the native 
language in most Evenki settlements also aggravates the state of affairs. At the same time, Turaev notes that the loss of the native language, unlike the mestization, has almost no effect on the ethnic identity of the Evenks. Certainly, a language is an important component of any ethnic culture, one of its criteria (Bulatova, 2017). This point of view is shared by the majority of researchers, and the contemporary authors continue to search for the correct model for the Evenki language revival as the main component of ethnic identity (Funk, 2013). So both traditional and alternative formats are used as models for the native language revival. The traditional format for the language revival is its study at school. In recent years, methodologists and teachers have been rethinking the present teaching process of the mother tongue. In 2010, the "Iukte" project was launched. This project is a series of career guidance activities and seminars for the Evenki language teachers (Andreeva, 2015). The purpose of this project is to evaluate and improve the quality of teaching the native language. The number of similar events aimed at exchanging experience and improvement of work on the language revival has been growing recently. In 2016 Yakutsk hosted the All-Russian seminar on the methodology of the development of a modern textbook on ethno-cultural education. The seminar participants shared up to date ways of teaching the native language to the indigenous small-numbered peoples of the North in educational institutions. In their talks participants analyzed current methods and described new educational methods in the field of the native language preservation, including the Evenki language (Semenova, Bolotaeva, Lekhanov, 2016).

In addition to being studied at school, the Evenki language is actualized due to the organization of ethnic holidays and festivals. Thus, the intelligentsia pays attention not only to the cultural, but also the linguistic features of the Evenki ethnos (Povorozniuk, 2014). Another form of the language revival is the creation of books in the Evenki language both through translations and publications of the Evenki authors. In the article "Translation of the Bible as a condition for preserving the spirituality and language of the Evenks" (Bulatova, 2014) N.Ia. Bulatova acknowledges the positive impact of the publication of the Evenki language books on the language development. In her opinion, when creating books, it is important to take into account the presence of several dialects of the Evenki language. N.N. Seredkina writes about the important role of fiction in the Evenki language revitalization (Seredkina, 2016). Like Bulatova, she draws attention to such peculiarity of the Evenki literature development as the existence of bilingual writers, and also indicates the importance of translating texts for the language development.

The discussion on the model and formats of the Evenki language revitalization continues in the scientific community. Some of its participants adhere to the synthetic view, believing that the language revival is possible by the attraction of diverse forces: scientific, public, educational and political. Speaking about the loss of native language N.P. Koptseva (Koptseva, 2014) accentuates the important role of state bodies in terms of preserving the culture of small ethnic groups and solving the problem of the native language revival. The same point of view is supported by a number of other specialists (Andreeva, Struchkov, 2015), according to whom the purposeful language policy, the work of scientists and peoples themselves may help revive the Evenki language.

Thus, the issue of the Evenki language revival is in the focus of attention of many scientists who offer different formats for solving this problem. The purpose of this article is to 
highlight, in our opinion, the most productive strategies for revitalizing the Evenki language. One of such strategies is publishing literature in the Evenki language.

\section{The dynamics of the literature publication in the Evenki language \\ (from the end of the $19^{\text {th }}$ to the first decades of the $21^{\text {st }}$ century)}

Consideration of publishing literature in the Evenki language as one of the priority strategies in the context of the language revival is conditioned by the data of sociological surveys among the Evenks. The survey results show a consistently positive attitude of the respondents to national folklore during the last 20 years. Songs, national fairy tales continue to have great significance for some Evenks. Besides, scientists mark an encouraging trend in teaching children songs in the Evenki language (Krivonogov, Ermilova, 2017). Therefore, the publication of books in the Evenki language is an opportunity not only to fix the Evenki oral folk art, but also to continue the practice of familiarizing the younger generation with the national culture through language. Undoubtedly, this practice should involve publishing not only folklore texts, but also fiction and textbooks. The creation of texts in the Evenki language has its own history, in view of which one can draw a conclusion about the trend of its steady positive development.

The first experience of publishing books in the Evenki language dates back to the $19^{\text {th }}$ century. At that time books of religious content, letters, dictionaries, the first grammar of the Evenki language were published, e.g. the following books: The Gospel of our Lord Jesus Christ According to Matthew in the Tungus language published in Kazan in 1881; Short Catechism, Daily Prayers and the Gospel for the Holy Easter in the Tungus language published in Kazan in 1881; The Short Tungus Dictionary published in
Moscow in 1859; The Tungus Language Primer published in Moscow in 1858. The first examples of books in the Tungus language mark the preprofessional stage in the formation of the Evenki literary school.

The turn of the 1920s and 1930s saw a new stage, connected then with the professional research of scientists interested in the development of the Evenki language. Collectors of the Tungus folklore played an important role in this process. Among them there was Vasily Silich Pezhemsky, one of the first pioneers who began to collect and process the Evenk folklore. Thanks to him the Evenki fairy tales came out as separate editions in 1937-1938. But the foundation of modern scientific research in the field of studying the Evenki language in the first half of the $20^{\text {th }}$ century was laid by G.M. Vasilevich. She made the first attempt to create the Evenki alphabet (Vasilevich, 1928), later she also compiled the Evenki-Russian dictionary with all dialects (Vasilevich, 1934) and described the peculiarities of the Tungus language in detail (Vasilevich, 1940). M.G. Voskoboinikov, a collector and researcher of folklore and literature of the peoples of the North, made a great contribution to the systematization and interpretation of the Evenki fairy tales. Later, based on the records, collected by him, professionals created written literary texts, among which the fairy tales and the heroic epic were prevalent, because, as noted above, they are of great importance for the Evenks. It is quite difficult to draw a line between the tale, in particular the fairy tale, and the epic, as some of the tales are sung in the same way as the epic (Voskoboinikov, 1973). The tales about animals, the most common among the Evenks, are usually called animal epic in folklore. However, the connection between the fairy tale and the epic is manifested not only in such proximity of the genres. The Evenki fairy tales are inherently epic. The analysis of a number of the Evenki 
fairy tales and the heroic epic "Brave Sodani the Bogatyr" made it possible to identify a number of epic features being standard in fairy tales, which explains the importance and significance of familiarizing the younger generation with national literary works. Among these features there are the possibility of combining small-sized fairy tales and tales concentrating around one character in cycles; demonstration of the tripartite nature of the world; the narrator making use of the epic formula of the time flow ("chronoact"); the presence of stylistic originality characteristic of the epic (epithets, hyperbolization in describing the place, detailed description of events, personification); the embodiment of material and spiritual values of national culture in the literary works; introduction into fairy tales of a special kind of endings, demonstrating the oldest mythological representations of the Evenks about animals, the surrounding nature as a whole (Seredkina et al., 2017).

Through the use of the above epic features, the ideological sense is laid, namely the Evenks' traditional views on the world order, which raise the tale to the level of epic, adult perception of the world.

One of the most important stages in the formation of the strategy for the language revival was the appearance of writing, originally on a Latin graphic basis, and from 1937 on a Cyrillic basis. This allowed publishers to print more editions of both fiction and educational literature in the Evenki language. There came out the first Evenki fiction books, in particular Naumov's story "How I Killed a Beamed Buck", printed as a separate book in the publishing house "Molodaya Gvardiya". Classical works of the national literary school were created in this period. Among them, there is a story "The Red Suglan" (1938) and chapters from the short novel "Margesha's Dreams Come True" by Nikita Sakharov.

In the 1940s - early 1960s, which were called the period of stagnation in art, there were created works of various genres. These were the poems by I. Kirillov, A. Khromov, N. Petrov, S. Monokonov, V. Solovyov; P. Savin's autobiographical novel "The Second Birth"; N. Lamatkanov's autobiographical story "Kachona”; G. Konenkov's story “The Family of Alena Uvachan".

The second half of the 1960-1990s is known as the period of artistic self-identification of the Evenki literature. At this stage, authors created such works which will become the classics of the Evenki literature later. These authors included poets Alitet Mikhailovich Nemtushkin, Dmitry Aprosimov and Nikolai Oegir, and prose writer Galina Ivanovna Varlamova-Kaptuke. Children's literature was also published: "Kunakardu" ("To Children") by A.N. Myreev, stories, short stories, tales and short novels. At the same time the Evenki language entered a new phase of its development. The practice of translating literary texts into another language began to develop. The works of the Evenki authors were often available in Russian. In particular, the poems by the Evenki poet Davlan-Nerguneev and "The Legend of Yermak" by A. Achkin were published in Russian. And vice versa, the masterpieces of Russian literature were translated into the Evenki language. For instance, A. Platonov made the first translation into the Evenki language of Pushkin's poem "Monument", in 1939 N. Sakharov and A. Salatkin translated into their native language "Old Woman Izergil" by M. Gorky, P. Savin translated "Stories" from the "ABC Book" by L.N. Tolstoy, and A. Nemtushkin translated "The Fairy Tale of the Fisherman and the Fish" by A.S. Pushkin. The poems for children by Soviet authors (A. Barto, S. Marshak) were translated into the Evenki language, too. Translation of spiritual literature was also carried out. In 1995, in Stockholm, at the Institute for Bible Translation, the Evenki linguist scholar and folklorist A.N. Myreeva translated "Stories about God" into the Evenki language. 
At the present stage (1990s-2000s), when the situation of the diminishing role of the Evenki language becomes the most noticeable, the problem of the language actualization becomes even more acute. And one of the steps in this direction is the active continuation of the creation of literature, educational and fiction in the Evenki language. The books of various genres are published. Among them there are collections with small genres of oral folk art, stories, fairy tales, poetry for educational and extra-curricular work; textbooks for schoolchildren who study the Evenki language; dictionaries; the RussianEvenki phrase books; encyclopaedias.

Along with the practice of translating literature from Russian into the Evenki language, the Evenki literature is enriched with translations of fairy tales from Chinese ("The Horse Wrangler and the Beautiful Phoenix" translated from Chinese by Madi Tiulemisov, Kazan, 2011). In 2017, in order to create conditions for the preservation and transfer of the cultural heritage of the indigenous peoples of the Evenki Municipal District to future generations, a special publishing project was implemented under the guidance of N.P. Koptseva, the Doctor of Philosophical Sciences, Professor, Director of the Krasnoyarsk Regional Public Organization "The Community of Enlighteners in Krasnoyarsk". A number of stories have been published for children and adults interested in the Evenki culture within the framework of this project. These are the stories "Who Invented the Christmas Tree?", "The Runaway Pancake", "The Power of Faith", "Traces", etc. The books are bilingual - in the Evenki and Russian languages, which makes the stories more understandable by the readership. The translation into the Evenki language was made by the teachers of the Evenki language Nina Petrovna Oegir and Nina Alexeyevna Kayanovich. In addition to these publications, there were written monographs on the analysis of similar projects in China, Norway, Canada, and other scientific works (Koptseva et al., 2017).

This practice is a necessary step for not only preserving the language, but also for its revival and actualization. The support of such projects by the authorities can turn out fruitful, on the one hand, for the maintenance of the existence of languages that are on the brink of extinction, on the other hand, for a deeper study of the native language among representatives of the Evenki community.

\section{Internet technologies} as a modern format

\section{for the Evenki language revival}

The modern system of Internet communications provides a wide opportunity for the introduction of new formats aimed at revitalizing the Evenki language. This strategy contributes to the inclusion of the indigenous peoples in the overall flow of intercultural interaction. Today the question is raised about the need for each nation to present its unique culture, language, historical and cultural traditions in the global Internet to transmit this information to the entire world community and to the own younger generation (Zhozhikov, 2012). In addition, the actualization of the language is also facilitated by socio-cultural scientific research, devoted to various aspects of ethnic culture, which in one way or another concern the language situation. Yet, today the available scientific studies on the Evenki language are scattered in the Internet. One of the modern formats that take into account the complex nature of the language revitalization problem is the project, whose name speaks for itself- "The Evenki Language Revival". In search of new formats for the Evenki language revival the scientists of the Department of Culture Studies of the Siberian Federal University turned to the idea of creating a unique educational and intellectual 
Internet resource https://www.evenkrenaissance. com/. The choice of a digital format for solving the problem of the Evenki language revival was conditioned by its congeniality to the young audience and modern trends in technological development.

Access to the resource is unrestricted. Anyone can visit the website of the project, which contains materials on the Evenki language. For this project there has been created a scientific team, whose members have participated in ethnocultural expeditions and scientific research since 2010. The collected material and the results of the team's scientific work are being used to fill certain sections of this site. Today, the site includes 9 sections: general information about the project, audio library, scientific studies of the Evenki language, the deer encyclopaedia, historical and cultural memories, archives and expeditions, information about the project team, contacts, interviews with native speakers. 3 more sections are being developed: folklore, mathematics in the Evenki language, stories for children in the Evenki and Russian languages.

The information is presented mainly in Russian. In this case, the Russian language is a means of conveying some information about the specifics of the Evenki language. In addition, Russian acts not only as a tool for the transfer of certain knowledge, but also as a resource that makes the Evenki language more available to the younger generation, as well as to all people who are interested in the Evenki culture. Rich material in the Evenki language is presented in the section "Audio Library", which contains classical and modern audio recordings of the Evenki language; educational, everyday texts and fiction. In addition to audio records, the project "The Evenki Language Revival" includes useful reference information about Evenkia, its inhabitants and the Evenki language. There is news about the Evenks living outside Evenkia, too. Also on the site there are books in the Evenki language, textbooks, fiction, documentaries and photographs. The section "Scientific research of the Evenki language" provides access to materials on the Evenki language and Evenki culture. They include scientific articles, monographs, and textbooks in the Evenki language, etc.

In general, this project is aimed not only at preserving the Evenki language in the new digital format, but also at introducing it to both the younger generation and adults, everybody who cares about the Evenki culture. The creation of a virtual information and intellectual space in an age of universal interaction through the Internet is one of the most effective solutions to the task of revitalizing languages at the stage of extinction.

\section{Conclusion}

The issue of reviving endangered indigenous languages continues to be at the centre of attention not only for the representatives of indigenous peoples themselves, but also for the authorities and the scientific community. The joint efforts of all parties allow them taking specific steps towards solving the problem of the decreasing role of national languages in modern living conditions. Among the priority directions for the Evenki language revival are the following:

1. Maintaining a policy aimed at preserving and developing the traditional way of life of the Evenks, namely encouraging the older generation to communicate in their native language, at least with the family members. It is the family that lays the foundation for the children's speech from birth; so this practice is recognized as one of the most priorities in maintaining the "life" of the Evenki language.

2. Preservation of traditional forms of work for the Evenks, since their language culture is 
connected with them. Within the framework of this project, for example, nomadic kindergartens and special ethno-cultural children's camps are being created.

3. Despite the fact that the statistical data of surveys $(85.2 \%$ of children under 10 years who study the Evenki language at school do not understand it) show that studying the native language at school does not save the Evenks from linguistic assimilation (Krivonogov, Ermilova, 2017), it is necessary to continue improving the methods of teaching the Evenki language at school by updating not only the content of educational literature (lexical, illustrative material), but also the technologies of communicating the national culture through the study of the mother tongue the Evenki language.

4. Maintenance of the practice of creating literature in the Evenki language with a parallel translation into Russian as the language of communication of most Evenks. As the survey results show, over the past 20 years, such genres of national folklore as songs and fairy tales have retained their significance for some Evenks. In addition, there is a positive trend in teaching children songs in the Evenki language (Krivonogov, Ermilova, 2017).

5. Creation and maintenance of new formats for the revival of the Evenki language based on modern Internet technologies.

\footnotetext{
Wikipedia. The free encyclopedia. Available at: https://ru.wikipedia.org/wiki/Эвенкийский_язык.
}

\section{References}

Alpatov, V.M. (2013). Iazykovaia politika v sovremennom mire [Language policy in the modern world], In Nauchnyi dialog [Scientific dialogue], 5 (17), 8-28.

Amosov, A.E., Bokova, V.I., Bakhova, N.A. (2012). Korennye malochislennye narody v usloviiakh global'nykh transformatsii. Chast' 1 . Kontseptual'nye i metodologicheskie osnovy issledovaniia. Etnokul'turnaia dinamika korennykh malochislennykh narodov Krasnoiarskogo Kraia [Indigenous and Small in Number Peoples of the North Siberia under the Global Transformations (on the Material of the Krasnoyarsk Territory). Conceptual and Methodological Basis of the Research. Ethno-cultural Dynamics of Indigenous Peoples of the Krasnoyarsk Territory]. (Part 1). Russia, Krasnoyarsk, 640 p.

Andreeva, T.E. (2015). Ob osnovnykh napravleniiakh izucheniia iazyka i fol'klora evenkov [On the main directions of studying the language and folklore of the Evenks], In Arktika XXI vek. Gumanitarnye nauki [Arctic in the XXI century. Humanities, 3(6), 85-92.

Andreeva, T.E., Struchkov, K.N. (2015). O funktsionirovanii evenkiiskogo literaturnogo iazyka. [On the functioning of the Evenki literary language], In Filologicheskie nauki. Voprosy teorii i praktiki [Philological Sciences. Issues of theory and practice], 7-2, 20-23.

Atknine, V. (1997). The Evenki Language from the Yenisei to Sakhalin, In Senri Ethnological Studies, 44, 109-121.

Berezhnova, M., Pimenova, N.N. (2016). Rost sotsial'no-kul'turnogo raznoobraziia kak rezul'tat mezhetnicheskikh kommunikatsii: iakuty s ozera Essei [The growth of socio-cultural diversity as a result of inter-ethnic communications: the Yakuts from Lake Yessey]. In Sotsiodinamika [Socio-dynamics], 4, 28-40, available at: http://e-notabene.ru/pr/article_18296.html. DOI: 10.7256/2409-7144.2016.4.18296.

Berezhnova, M.I., Pimenova, N.N. (2018). Istoriia formirovaniia subetnosa esseiskikh iakutov (na materiale analiza nauchnykh issledovanii i arkhiva Krasnoiarskogo kraevogo kraevedcheskogo muzeiia [The history of the formation of the subethnos of the Yessey Yakuts (based on the analysis of 
scientific research and the archives of the Krasnoyarsk Regional Museum of Local Lore)], In Severnye Arkhivy i Ekspeditsii [Northern Archives and Expeditions], 4, 30-52.

Bukova, M.I. (2016). Osobennosti etnokul'turnogo samosoznaniia etnicheskoi gruppy chulymtsev, kompaktno prozhivaiushchikh na territorii derevni Pasechnoe Tiukhtetskogo raiona Krasnoiarskogo kraia (Tsentral'naia Sibir') [Features of ethnocultural self-identity of the ethnic group of Chulyms, living compactly in Pasechnoye village in the Tyukhtetsky District of the Krasnoyarsk Territory (Central Siberia)], In Sotsiodinamika [Socio-dynamics], 4, 41-51, available at: http://e-notabene.ru/pr/ article_18414.html. DOI: 10.7256/2409-7144.2016.4.18414.

Bulatova, N.Ia. (2017). Iazykovye protsessy v epokhu obshchestvennykh transformatsii (na materiale evenkiiskogo iazyka) [Language processes in the era of social transformations (on the basis of the Evenki language)], In Teoreticheskaia i prikladnaia lingvistika [Theoretical and applied linguistics], 3(2), 5-19.

Bulatova, N.Ia. (2014). Perevod Biblii kak uslovie sokhraneniia dukhovnosti i iazyka evenkov [Translation of the Bible as a condition for preserving the spirituality and language of the Evenks], In Materialy vserossiiskoi nauchno-metodicheskoi videokonferentsii "Obuchenie inostrannomu iazyku studentov vysshikh i srednikh obshcheobrazovatel'nykh uchrezhdenii na sovremennom etape" [Materials of the all-Russian scientific and methodical videoconference "Teaching a foreign language for students of higher and secondary educational institutions at the present stage], 196-201. Blagoveshchensk.

Degtiarenko, K.A. (2015). Aktual'noe sostoianie korennykh malochislennykh narodov Severa [Topical state of the indigenous small-numbered peoples of the North], In Sotsiodinamika [Sociodynamics], 10, 39-57.

Dvoretskaia, A.P. (2017). Razvitie Eniseiskogo Severa v postanovleniiakh Krasnoiarskogo kraevogo komiteta Kommunisticheskoi partii Sovetskogo Soiuza. 1940-1971 gody. [Development of the Yenisei North in the resolutions of the Krasnoyarsk Krai Committee of the Soviet Union Communist Party. 1940-1971. Northern Archives and Expeditions Дворецкая, А.П. (2017)], In Severnye Arkhivy i Ekspeditsii [Northern Archives and Expeditions], 1, 41-50.

Felde, O.V. (2011). The Ethno-Linguistic Situation in the Krasnoyarsk Territory at the Beginning of the Third Millennium, In Journal of Siberian Federal University. Humanities \& Social Sciences, 4 (7), 919-929.

Funk, D. A. (2013). Contemporary "Traditional" Cultures of the Peoples of the North, In Anthropology \& Archeology of Eurasia, 52(3), 8-12. DOI: 10.2753/AAE1061-1959520301.

Kicheeva, K.A., Starko, E.A., Reznikova, K.V. (2015). Politiko-pravovye osnovy kul'turnykh vzaimodeistvii severnykh narodov Rossiiskoi Federatsii: istoriia i sovremennost' [Political and legal bases of cultural interaction of northern peoples of the Russian Federation: history and modernity], In Sotsiodinamika [Socio-dynamics], 5, 114-122, available at: http://e-notabene.ru/pr/article_15320.html. DOI: $10.7256 / 2409-7144.2015 .5 .15320$.

Kirko, V.I. (2015). Postsovetskie praktiki sokhraneniia etnokul'turnoi identichnosti korennykh narodov Severa i Sibiri v Krasnoiarskom krae Rossiiskoi Federatsii [Post-Soviet practices of preserving the ethno-cultural identity of the indigenous peoples of the North and Siberia in the Krasnoyarsk Territory of the Russian Federation], In Sotsiodinamika [Socio-dynamics], 6, 113-133, available at: http://e-notabene.ru/pr/article_15607.html DOI: 10.7256/2409-7144.2015.6.15607 
Kirko, V.I., Kuznetsova, Yu. S., Malakhova, E.V., Vasil'ev, E.A. (2017). Otsenka kachestva zhizni zhitelei raiona Arkticheskoi zony na primere poselka Respubliki Sakha (Iakutiia) [An estimation of life quality of Arctic zone inhabitants on the example of a Republic Sakha (Yakutia) settlement]. In Severnye Arkhivy $i$ Ekspeditsii [Northern Archives and Expeditions], 3, 21-37.

Kistova, A.V., Zamaraeva, J.S., Pimenova, N.N., Reznikova, K.V., Koptseva, N.P., \& Seredkina, N.N. (2016). Regional Peculiarities in Modernization Processes within the Territories of Central Siberia, In International Review of Management and Marketing, 6(4). 857-865.

Kolesnik, M.A. (2014). Obzor izuchenia fol'klora korennykh narodov Severa [Review of the folklore study of the indigenous peoples of the North], In Litera, 3, 39-59, available at: http://e-notabene. ru/fil/article_13998.html. DOI: 10.7256/2409-8698.2014.3.13998.

Kononova,E.S.(2017). Metodicheskieaspekty upravleniiaustoichivym sotsial'no-ekonomicheskim razvitiem severnykh territorii regiona [Methodical aspects of managing the sustainable social and economic development of the northern territories of the region], In Severnye Arkhivy i Ekspeditsii [Northern Archives and Expeditions], 3, 38-43.

Koptseva, N.P. (2014). K voprosu o gosudarstvennoi politike v oblasti sokhraneniia iazykov korennykh malochislennykh narodov Severa [On the issue of state policy concerning the preservation of the languages of the indigenous small-numbered peoples of the North], In Arktika i Sever [Arctic and the North], 16, 34-40.

Koptseva, N.P., Amosov, A.E., Luzan V.S. et al. (2017). Sozdanie detskoi literatury korennykh malochislennykh narodov Evenkiiskogo munitsipal'nogo raiona Krasnoiarskogo kraia: Analiz analogovykh proektov Kitaia, Norvegii, Kanady, drugikh stran [Creation of children's literature of the indigenous small-numbered peoples of the Evenkiysky Municipal District of Krasnoyarsk Krai: Analysis of similar projects in China, Norway, Canada and other countries]. Publishing Solutions, $66 \mathrm{p}$.

Koptseva, N.P., Khizhniakova, A.N., Reznikova, K.V. (2017). K voprosu o kontseptakh iazykov korennykh narodov Krasnoiarskogo kraia [On the issue of the concepts of the languages of the indigenous peoples of Krasnoyarsk Krai]. In Severnye Arkhivy i Ekspeditsii [Northern Archives and Expeditions], 1, 6-22.

Krivonogov, V.P., Ermilova, E.S. (2017). Dinamika etnicheskikh protsessov u evenkov. Sozdanie proizvedenii detskoi literatury na evenkiiskom iazyke: monografiia. Pod.red N.P. Kopstevoi [Dynamics of ethnic processes of the Evenks. Creation of children's literature in the Evenki language: monograph. Ed. by N.P. Koptseva]. Publishing Solutions, 9-42.

Libakova, N.M. (2015). Formirovanie pozitivnoi etnicheskoy identichnosti indigennykh narodov posredstvom dekorativno-prikladnogo iskusstva (rez'ba po kosti) [The formation of positive ethnic identity of the indigenous peoples through arts and crafts (bone carving)], In Sovremennye problemy nauki i obrazovaniia [Modern problems of science and education], 1 (1), 1887.

Libakova, N.M. (2015). Upravlenie zdravookhraneniem dlia korennykh narodov tsentral'noi Sibiri (na materiale analiza Krasnoiarskogo Kraia) [Health Sphere Management for the Indigenous Peoples of Central Siberia (on the Material of the Krasnoyarsk Krai Analysis)], In Trendy i upravlenie [Trends and Management], 4, 380-394. DOI: 10.7256/2307-9118.2015.4.16854

Mamontova, N.A. (2013). Na kakom iazyke govoriat nastoiashchie Evenki? [What language do the real Evenks speak? Discussions around the nomadic kindergarden]. In Etnograficheskoe obozrenie [Ethnographic Review], 2, 70-91.

$$
-625-
$$


Pimenova, N.N. (2016). Mekhanizmy sotsiokul'turnykh izmenenii korennykh malochislennykh narodov Sibiri i Severa [Mechanisms of Socio-Cultural Changes concerning the Indigenous SmallNumbered Peoples of Siberia and the North: Concept of Cultural Trauma by P. Sztompka], In Sotsiodinamika [Socio-dynamics], 3, 37-45, available at: http://e-notabene.ru/pr/article_18210.html DOI: 10.7256/2409-7144.2016.3.18210.

Povoroznyuk, O. (2014). Belonging to the land in Tura: reforms, migrations, and identity politics in Evenkia, In Journal of Ethnology \& Folkloristics, 8(2), 33-51.

Reznikova, K.V. (2015). Sokhranenie traditsionnykh iazykov korennykh malochislennykh narodov kak obespechenie osnovy kul'turnogo raznoobraziia regiona [Preservation of the traditional languages of the indigenous small-numbered peoples as the pre-condition for the cultural diversity in the region], In Sovremennye problem nauki i obrazovaniia [Modern problems of science and education], (1-1), 1879.

Reznikova, K.V. (2016). K voprosu ob epicheskom kul'turnom nasledii korennykh malochislennykh narodov Krasnoiarskogo Kraia [On the issue of the epic cultural heritage of the indigenous smallnumbered peoples of the Krasnoyarsk Krai], In Litera, 2, 20-34, available at: http://e-notabene.ru/fil/ article_18917.html. DOI: 10.7256/2409-8698.2016.2.18917.

Reznikova, K.V., Seredkina N.N., Koptseva N.P., Zamaraeva Ju.S. (2016). Regoinal'naia spetsifika sotsial'nykh tsennostei i ikh vlianie na protsessy modernizatsii territorii tsentral'noi Sibiri (na materiale issledovanii Krasnoiarskogo Kraia) [Regional specificity of social values and their influence on the modernization processes on the territories of Central Siberia (based on the research of Krasnoyarsk Krai)], In Economichnil chasopis-XXI [Economic Annals-XXI], 160 (7-8), 92-95.

Semenova, S.S, Bolotaeva, O.L., \& Lekhanov, S.B. (2016). Materialy Vserossiiskogo seminara po voprosam metodologii razrabotki sovremennogo uchebnika po etnokul'turnomu obrazovaniiu [Proceedings of the All-Russian Seminar on the methodology of a modern textbook on ethno-cultural education], Yakutsk, March 22-23. Moscow, 63 p.

Seredkina, N.N. (2016). Evenk Children's Literature: History and Specific Features, In Journal of Siberian Federal University. Humanities \& Social Sciences, 9(9), 1994-2004. DOI: 10.17516/19971370-2016-9-9-1994-2004.

Seredkina, N.N. (2016). Teoreticheskaia model' pozitivnoi etnicheskoi identichnosti i mekhanizmy ee formirovaniia [Theoretical model of positive ethnic identity and the mechanisms of its formation], In Sotsiodinamika [Socio-dynamics], 2, 37-46, available at: http://e-notabene.ru/pr/article_17690.html. DOI: 10.7256/2409-7144.2016.2.17690.

Seredkina, N.N., Smolina, M.G., \& Kistova, A.V. (2017). Vlianie eposa na skazki korennykh narodov Severa i Sibiri [The influence of the epic on the tales of the indigenous peoples of the North and Siberia], In Sibirskii antropologicheskii zhurnal [Siberian anthropological journal], 1 (06), 62-73.

Sitnikova, A.A. (2015a). Demografiia i migratsiia v poselkakh korennykh malochislennykh narodov Krasnoiarskogo Kraia (Pasechnoe, Essei, Surinda, Farkovo, Nosok, Karaul) [Demography and migration in the villages of the indigenous small-numbered peoples of Krasnoyarsk Krai (Pasechnoe, Yessey, Surinda, Farkovo, Nosok, Karaul)], In Sovremennye problem nauki i obrazovaniia [Modern problems of science and education], (1-1), 1881-1881.

Sitnikova, A.A. (2015b). Korennoe obrazovanie: aktual'noe sostoianie i problem [Indigenous Education: current status and problems], In Pedagika i prosveshchenie [Pedagogy and Education], 3, 300-311. 
Struchkov, K.N. (2005). K voprosu obucheniia evenkiiskomu iazyku v usloviiakh dvuiazychiia [On teaching the Evenki language in the bilingual environment], In Obrazovanie $i$ ustoichivoe razvitie korennykh narodov Sibiri: materialy Mezhdunarodnoi nauchno-prakticheskoi konferentsii [Education and sustainable development of the indigenous peoples of Siberia: materials of the International scientific and practical conference]. Novosibirsk, 699-702.

Struchkov, K.N. (2011). Sotsiolingvisticheskie factory iazykovoi kartiny mira evenkov v RS (Ia) [Sociolinguistic factors of the linguistic picture of the Evenki world in the Republic of Sakha (Yakutia)], In Vestnik Zabaikal'skogo gosudarstvennogo universiteta [Bulletin of Transbaikal State University], 2(69), 38-44.

Turaev, V.A. (2006). Assimiliativnye protsessy u dal'nevostochnykh evenkov [Assimilation processes of the Far Eastern Evenks], In Vestnik Dal'nevostochnogo otdeleniia Rossiiskoi akademii nauk [Bulletin of the Far Eastern Branch of the Russian Academy of Sciences], 3, 104-121.

Vasilevich, G.M. (1928). Pamiatka tungusam-otpusknikam [Memo to the Tungus holidaymakers]. Leningrad, Steklograf, 28 p.

Vasilevich, G.M. (1934). Evenkiisko-russkii (tungussko-russkii) dialektologicheskii slovar' [Evenki-Russian (Tungus-Russian) dialectological dictionary]. Leningrad, Lengorlit, 244 p.

Vasilevich, G.M. (1940). Ocherk grammatiki evenkiiskogo (tungusskogo) iazyka [Outline on the grammar of the Evenki (Tungus) language]. Leningrad, the State Educational and Pedagogical Publishing House of the People's Commissariat of the RSFSR, 196 p.

Voskoboinikov, M.G. (1973). Kto dal evenkam solntse. Skazki, predaniia i ustnye rasskazy evenkov [Who gave the Evenks the sun. Fairy tales, legends and oral stories of the Evenks]. Irkutsk, East Siberian Book Publishing House, 248 p.

Zhozhikov, A.V. (2012). Iazykovoe i kul'turnoe raznoobrazie korennykh malochislennykh narodov Severa na tsifrovykh nositeliakh i v kiberprostranstve [The linguistic and cultural diversity of the indigenous small-numbered peoples of the North on digital media and in cyberspace], In Mezhdunarodnaia nauchnaia konferentsiia "Kul'turnoe nasledie Severnoi Evrazii: problem $i$ perspektivy osvoeniia" [International scientific conference "Cultural heritage of Northern Eurasia: problems and perspectives of development"], 111-116. Yakutsk.

\title{
Возрождение эвенкийского языка:
}

\section{традиционные и современные форматы}

\author{
Н.Н. Середкина, Е.С. Стручева \\ Сибирский федеральный университет \\ Россия, 660041, Красноярск, пр. Свободный, 79
}

Процесс языковой ассимиляции, начавшийся ещче в 90-е г2. ХХ в., оказал сильное влияние на сокращение численности эвенков, владеющих родным языком. На современном этапе развития языка актуальным и своевременным становится вопрос его возрождения. В данной статье предлагается рассмотреть стратегии ревитализации эвенкийского языка, связанные, с одной стороны, с продолжением традиционных практик сохранения языка, с другой-с появлением новых современных форматов, позволяющих расширить возможности приобщения к эвенкий-

$$
-627-
$$


скому языку, культуре эвенков большей аудитории. Представлены приоритетные направления возрождения эвенкийского языка. Среди них поддержание политики, направленной на сохранение и развитие традиционного образа жизни эвенков; осуществление практики языкового погружения; продолжение практики создания литературы на эвенкийском языке; приобщение большей аудитории к эвенкийскому языку посредством современных интернет-технологий.

Ключевые слова: эвенкийский язык, возрождение, эвенки, эвенкийская литература, Интернет.

Исследование выполнено при поддержке АО «Востсибнефтегаз» в рамках реализачии проекта по выполнению научно-исследовательских работ «Возрождение эвенкийского языка».

Научная специиальность: 24.00.00 - культурология. 